KREATIF

Jurnal Ilmiah

Prodi Manajemen Universitas Pamulang
ISSN: 2339-0689 (Print), ISSN 2406-8616 (Online)

Volume 7, No 1 Juni 2019, (Halaman 66-79)

Tersedia online di http://openjournal.unpam.ac.id/index.php/kreatif

\title{
PENGARUH BUDAYA ORGANISASI DAN TURNOVER \\ KARYAWAN TERHADAP KINERJA KARYAWAN \\ (Study pada PT Citra Rasa Betawi - JABODETABEK)
}

\author{
Muhamad Abid \\ Program Studi Manajemen \\ Universitas Pamulang \\ dosen02466@unpam.ac.id
}

\begin{abstract}
ABSTRAK
Dunia bisnis dewasa ini semakin berkembang pesat, kompetitor semakin bertambah banyak terutama di bisnis kuliner, jika suatu perusahaan ingin tetap eksis dan dapat mencapai tujuannya, kinerja karyawan adalah salah satu kunci keberhasilannya, penelitian kualitatif ini dilakukan untuk mengetahui pengaruh budaya organisasi (X1), turnover (X2), terhadap kinerja (Y) di PT Citra Rasa Betawi baik secara parsial maupun secara simultan.

Karyawan PT Citra Rasa Betawi di JABODETABEK yang menjadi populasi sebanyak 670 karyawan dan sampelnya sebanyak 250 karyawan dengan kuisioner masing-masing variabel memiliki 12 pernyataan yang didistribusikan kepada 250 responden.

Hasil pengolahan data penelitian menunjukan : 1) Budaya Organisasi memiliki pengaruh positif dan signifikan pada Kinerja karyawan di PT Citra Rasa Betawi secara parsial. 2) Turnover memiliki pengaruh positif dan signifikan pada Kinerja karyawan di PT Citra Rasa Betawi secara parsial. 3) Budaya Organisasi dan Turnover memiliki pengaruh positif dan signifikan pada Kinerja karyawan di PT Citra Rasa Betawi baik secara parsial maupun secara simultan. Dari hasil pengolahan data penelitian tersebut perusahaan baiknya dapat meningkatkan inisatif dan integritas karyawan guna peningkatan kinerja karyawan kemudian perusahaan harus meningkatkan peluang berkarier untuk karyawannya, agar karyawan memiliki masa depan dengan jenjang kariernya sehingga tingkat turnover karyawan menurun.
\end{abstract}

Kata Kunci : Budaya Organisasi, Turnover dan Kinerja

\section{ABSTRACT}

Today's business world is growing rapidly, more and more competitors, especially in the culinary business, if a company wants to still exist and can achieve its goals, employee performance is one of the keys to its success, this qualitative research is conducted to determine the influence of organizational culture (X1), turnover (X2), on performance $(Y)$ at PT. Citra Betawi taste both partially and simultaneously.

The employees of PT Citra Rasa Betawi in JABODETABEK which has a population of 670 employees and a sample of 250 employees with questionnaires for each variable have 12 statements distributed to 250 respondents.

The results of processing the research data show: 1) Organizational Culture has a positive and significant influence on employee performance at PT. Citra Betawi partially. 2) Turnover has a positive and significant effect on employee performance at PT. Citra Betawi partially. 3) Organizational Culture and Turnover has a positive and significant influence on employee performance at PT. Citra Betawi taste both partially and simultaneously. From the results of the research data processing the company 
should be able to increase employee initiative and integrity in order to improve employee performance then the company must increase career opportunities for its employees, so that employees have a future with a career path so that employee turnover rates decline.

Keywords: Organizational Culture, Turnover and Performance

\section{PENDAHULUAN}

\section{A. Latar Belakang Masalah}

Sumber Daya Manusia atau SDM didalam setiap kegiatan organisasi harus selalu berperan aktif, karena SDM lah yang menentukan terwujud atau tidaknya tujuan organisasi. SDM harus mampu mengembangkan potensi dirinya secara aktif, mau bekerja keras dan terus belajar, mempunyai motivasi yang kuat untuk menjadi sukses dengan terus menerus mengembangkan keahlian dan potensinya, SDM harus mempunyai rasa ingin tahu yang tinggi agar kaya dengan informasi dan mampu menyesuaikan diri dengan perkembangan teknologi seperti saat ini dijaman revolusi industry 4.0 yang mungkin sebentar lagi akan ke revolusi industry 5.0.

A.A Anwar Prabu Mangkunegara (2014: 9) mengutip dari Bambang Krisyanto (1991:3) menjelaskan pengertian kinerja adalah suatu perbandingan hasil kerja yang bisa dicapai seorang karyawan dengan peran serta karyawan dalam satuan waktu (lajimnya per jam)". Kemudian penulis berpendapat mengenai pengertian kinerja yang menurut penulis adalah sebuah hasil kerja dari pekerjaan yang dilakukan karyawan yang diukur menggunakan satuan waktu baik secara kualitas maupun kuantitasnya berdasarkan jabatannya.

Mangkunegara (2005:113) menjelaskan budaya organisasi suatu nilai-nilai dan juga norma dalam organisasi yang dikembangkan kemudian dijadikan tingkah laku bagi anggota organisasi atau seperangkat asumsi atau sistem keyakinan untuk mengatasi masalah adaptasi internal dan integrasi eksternal. Kemudian penulis berpendapat mengenai pengertian budaya organisasi yang menurut penulis adalah serangkaian nilai-nilai, peraturan, norma-norma dalam organisasi yang diberlakukan didalam organisasi kemudian menjadi identitas organisasi tersebut.

Turnover menurut Zenffane yang dikutip oleh Kurniasari (2004) artinya adalah suatu keinginan yang timbul pada karyawan untuk melakukan sesuatu. Kemudian "turnover intention menurut Harnoto (2002:2) adalah intensitas keinginan karyawan untuk keluar dari perusahaan. Beberapa permasalahan didalam perusahaan yang biasanya menjadi penyebab terjadinya turnover intention, yaitu diantaranya keinginan seoarang karyawan untuk mendapatkan pekerjaan yang dianggap lebih baik". Kemudian penulis berpendapat mengenai pengertian turnover intention, yaitu suatu hasrat yang timbul pada seorang karyawan untuk keluar dari perusahaan karena perasaan tidak nyaman didalam perusahaan atau berharap akan mendapatkan peluang bekerja di perusahaan lain dengan gaji yang lebih besar, suasanakerja lebih nyaman dan jabatan yang lebih tinggi.

PT Citra Rasa Betawi sebuah perusahaan besar yang sedang berkembang di Indonesia, perusahaan ini bergerak dibidang restoran $(\mathrm{F} \& \mathrm{~B})$ yang mengutamakan kualitas produk makanan dan minuman juga service nya, PT Citra Rasa Betawi yang sudah berdiri sejak tahun 1992 dengan outlet pertamanya ada di Pondok Indah Mall dengan brand Kafe Betawi, pada saat ini PT Citra Rasa Betawi memiliki lebih dari 20 outlet di Jabodetabek dengan total karyawan mencapai 670 orang.

PT Citra Rasa Betawi saat ini sudah memiliki lima brand yang tersebar diseluruh Indonesia yaitu : 
1. Kafe Betawi brand yang menyajikan makanan tradisional khas betawi yang dikemas dalam konsep resto yang mewah, berkualitas namun harga tetap terjangkau.

2. Kafe Betawi Express konsepnya sama persis seperti Kafe Betawi namun dengan tampilan yang lebih simpel dan penyajian yang lebih cepat oleh karena itu dinamakan express.

3. Betawi Corner adalah brand yang menyajikan perpaduan antara konsep tradisional betawi dengan gaya coffee shop yang terlihat lebih elegan, makanannya lebih cepat saji dan terdapat aneka kopi didalamnya.

4. Barr \& Coffee brad peranakan dari Kafe Betawi ini yang sedikit keluar dari konsep tradisionalnya karena lebih menampilkan konsep coffee shop nya.

5. Kafe Betawi First adalah konsep premiumnya dari Kafe Betawi dimana didalam Kafe Betawi First ini menyajikan kopi dan juga aneka traditional drink.

Dalam pertumbuhan bisnisnya PT Citra Rasa Betawi sangat memperhatikan kinerja karyawannya agar perusahaan dapat terus berkembang menyesuaikan dengan perkembangan jaman, teknologi dan juga pekembangan customer, karena dewasa ini semakin banyak competitor bisnis di bidang F\&B baik tradisional food yang sejenis dengan PT Citra Rasa Betawi maupun, japanes food, korean food, western food, chines food. PT Citra Rasa Betawi harus memastikan kinerja karyawannya mampu membuat para customer nya tetap setia meskipun banyak competitor lain.

Berdasarkan paparan di atas judul penelitian yang penulis ingin kaji lebih mendalam adalah : "Analisis Pengaruh Budaya Organisasi dan Turnover Karyawan Terhadap Kinerja Karyawan Pada PT Citra Rasa Betawi”.

\section{B. Perumusan Masalah}

1. Seberapa positif dan signifikan pengaruh budaya orgnisasi di PT Citra Rasa Betawi terhadap kinerja karyawannya secara parsial ?

2. Seberapa positif dan signifikan pengaruh turnover orgnisasi di PT Citra Rasa Betawi terhadap kinerja karyawannya secara parsial ?

3. Seberapa positif dan sifnifikan pengaruh budaya organisasi dan turnover karyawan orgnisasi di PT Citra Rasa Betawi terhadap kinerja karyawannya baik secara parsial maupun secara simultan?

\section{TINJAUAN PUSTAKA}

\section{A. Manajemen Sumber Daya Manusia}

Suatu proses, system, atau cara mengelola peran manusia dan hubungan manusia dengan manusia lainnya dalam sebuah organisasi itulah yang sering dikenal dengan sebutan HRMS (Human Resource Management System) atau di Indonesia lebih familiar dengan MSDM (Manajemen Sumber Daya Manusia) . SDM juga disebut sebagai ilmu dan seni mengendalikan manusia karena SDM merupakan factor penting dalam menentukan keberhasilan dari sebuah perusahaan dalam mewujudkan mimpi-mimpinya yang tertuang didalam visi dan misinya perusahaan.

Beberapa ahli menjelaskan mengenai teori MSDM diantaranya Hisabuan (2006:1) MSDM adalah suatu ilmu dan seni dalam mengatur hubungan atau peranan seorang karyawan agar dapat efektif dan efisien dalam membantu terwujudnya tujuan perusahaan, karyawan dan masyarakat. Kemudian Simamora, (2001:3) menjelaskan MSDM adalah suatu pengelolaan, pemdayagunaan, pengembangan, penilaian dan pemberian balas jasa individu atau anggota organisasi atau kelopmpok pekerja. 
Penulis berpendapat bahwa manusia adalah perencana sekaligus pelaku dan penentu tercapai atau tidaknya tujuan suatu perusahaan sehingga manusia didalam perusahaan atau organisasi harus selalu berperan aktif dan menjadi dominan didalam setiap kegiatan atau aktifitas perusahaan, perusahaan harus mengakui hal tersebut dan dewasa ini perusahaan harus mengakui manusia yang ada diperusahaan sebagai asset yang nilainya paling tinggi bukan hanya sebagai sumber daya yang dari perspektif manfaat manusia hanya diadakan didalam perusahaan untuk dimanfaatkan sumber dayanya setelah tidak dapat dimanfaatkan maka manusia akan menjadi beban bagi perusahaan. Tetapi jika manusia didalam perusahaan diakui sebagai asset yang memiliki nilai paling tinggi maka perusahaan akan berusaha untuk tetap menjaga nilai tersebut bahkan meningkatkan nilainya, semakin lama karyawan bekerja disebuah perusahaan makan nilai karyawan tersebut semakin tinggi dan mampu memberikan nailai balik bagi perusahaan atau kontribusi bagi perusahaan yang lebih besar.

\section{B. Budaya Organisasi}

Suatu sikap atau prilaku yang dilakukan karyawan didalam sebuah organisasi berdasarkan nilai dan norma yang berlaku secara terus menerus, konsisten dan akhirnya menjadi sebuah kebiasa didalam organisasi tersebut itulah yang dinamakan budaya organisasi menurut penulis dalam penelitian ini namun penulispun mengutip beberapa referensi dari ahli teori budaya organisasi seperti Wibowo (2013:15) yang mengutip dari Edgar Schein menjelaskan budaya adalah suatu pola asumsi dasar yang dikembangkan dan ditentukan oleh suatu kelompok tertentu karena sudah mempelajari dan menguasi masalah adaptasi ekternal dan integrasi internal, yang telah bekerja dengan cukup baik untuk dipertimbangkan secara layak dan karena itu diajarkan kepada anggota baru sebagai cara yang dipersepsikan, berfikir dan dirasakan dengan benar dalam hubungan masalah tersebut.

Robbins dalam Sopiah (2008:128) budaya organisasi mengacu ke suatu sistem makna bersama yang dianut oleh anggota-anggota organisasi itu yang membedakan organisasi tersebut dengan organisasi lainnya. Berdasarkan pengertian budaya organisasi di atas, penulis berpendapat mengenai pengertian budaya organisasi yang menurut penulis adalah serangkaian nilai-nilai, peraturan, norma-norma dalam organisasi yang diberlakukan didalam organisasi kemudian menjadi identitas organisasi tersebut. Budaya organisasi harus diketahui, dipahami, dijunjung tinggi dan diimplementasikan oleh seluruh anggota organisasi baik oleh anggota yang sudah lama bergabung maupun oleh anggota yang baru bergabung.

\section{Turnover Intention}

Turnover menurut Zenffane yang dikutip oleh Kurniasari (2004) artinya adalah suatu niat atau keinginan yang timbul pada individu atau karyawan untuk melakukan sesuatu. Harnoto (2002:2) menyatakan, "turnover intention adalah kadar atau intensitas dari keinginan untuk keluar dari perusahaan. Banyak alasan yang menyebabkan timbulnya turnover intention, diantaranya adalah keinginan untuk mendapatkan pekerjaan yang lebih baik".

Kemudian penulis berpendapat mengenai pengertian turnover intention, yaitu suatu hasrat yang timbul pada seorang karyawan untuk keluar dari perusahaan karena perasaan tidak nyaman didalam perusahaan atau berharap akan mendapatkan peluang bekerja di perusahaan lain dengan gaji yang lebih besar, suasana kerja lebih nyaman dan jabatan yang lebih tinggi. Factor tenjadinya turnover menurut penulis adal dua diantaranya adalah factor internal yaitu semua hal dari dalam perusahaan yang membuat karyawan tidak nyaman dan akhirnya 
berfikir untuk mencari pekerjaan baru, kemudian factor eksternal adalah semua hal dari luar perusahaan yang sepertinya terlihat lebih baik atau dapat menjadi tempat pelarian dari perasaan tidak nyaman didalam perusahaan.

Turnover sering kali menjadi permasalahan didalam perusahaan karena dengan terjadinya turnover dianggap mengganggu kestabilan operasional perusahaan dimana ketika ada karyawan yang resign maka perusahaan harus merekrut karyawan yang baru, kemudian memberikan training dan edukasi kepada karyawan baru, pastinya ada biaya lebih yang harus dikeluarkan oleh perusahaan tetapi belum ada jaminan karyawan baru tersebut pasti sukses dan dapat berkontribusi besar diperusahaan, menyikapi hal tersebut perusahaan harus bisa untuk menganalisa fenomena turnover yang terjadi, dalam menganalisa fenomena turnover memang ada rumus untuk menghitung tingkat turnover, namun sebelum menghitung tngkat turnover baiknya perusahaan melihat terlebih dahulu karyawan yang resign itu siapa, jabatannya apa, dan levelnya apa, jika karyawan yang resign adalah karyawan yang levelnya staf dan jabatannya tidak terlalu penting di dalam perusahaan maka ketika tingkat turnover tinggi sebenarnya kondisi perusahaan masih aman dan baik-baik saja, namun ketika karyawan yang resign adalah karyawan yang berada di level dan jabatan strategis meskipun tingkat turnover nya rendah perusahaan harus waspada dan sangat berhati-hati.

\section{Kinerja}

Kinerja menurut Bambang Krisyanto dalam A.A Anwar Prabu Mangkunegara (2014: 9) adalah "perbandingan hasil yang dicapai dengan peran serta tenaga kerja persatuan waktu (lajimnya per jam)". Kemudian kinerja dijelaskan oleh Mangkunegara (2005:67) sebagai hasil kerja baik secara kualitas dan kuantitas yang dapat dicapai oleh pegawai dalam menjalankan pekerjaan sesuai dengan tugas dan tanggung jawab yang diberikan perusahaan kepadanya. Kemudian penulis berpendapat mengenai pengertian kinerja yang menurut penulis adalah sebuah hasil pekerjaan yang dilakukan pekerja baik dalam ukuran waktu, kualitas maupun kuantitas berdasarkan jabatannya.

Kinerja karyawanlah yang menentukan tercapai atau tidaknya tujuan suatu perusahaan, jika baik kinerja karyawan di dalam perusahaan makan kemungkinan tercapainya tujuan suatu perusahaan semakin besar, namun jika kinerja karyawan di perusahaannya tidak baik atau rendah maka dipastikan tujuan dari perusahaan tidak dapat tercapai, penulis berpendapat adanya persamaan kinerja karyawan dan kinerja perusahaan dimana kinerja karyawan adalah kinerja perusahaan dan begitupula sebaliknya kinerja perusahaan adalah kinerja karyawan.

\section{E. Kerangka Pemikiran}

Kerangka berfikir menurut Sugiyono (2011:60) merupakan sintesa dari teaoriteori yang biasa digunakan dalam pelatihan sehingga dapat menjelaskan secara operasional variabel yang diteliti, menunjukan pengaruh antara variabel pada berbagai populasi atau yang berbeda. Dalam kerangka pemikiran penelitian ini variable variable yang diteliti adalah budaya organisasi (X1), turnover (X2) dan kinerja karyawan (Y), dimana inputnya adalah visi, misi perusahaan, SDM, sarana dan prasaranan perusahaan, prosedur dan customer kemudian prosesnya adalah indicator dari variable budaya organisasi (X1) dan indicator dari variable turnover (X2), kemudian outcomenya adalah indicator dari variable kinerja karyawan (Y).

\section{F. Model Penelitian}

Cara ilmiah yang biasa digunakan untuk mendapatkan data dengan tujuan dan kegunaan tertentu disebut sebagai metode penelitian menurut Sugiyono (2013:24), dalam sebuah penelitian ada 4 (empat) kata kunci yang harus diperhatikan oleh 
setiap penulis dalam membuat suatu karya tulis atau penelitian diantaranya yaitu cara ilmiah, data, tujuan dan kegunaan dari penelitian tersebut.

Dalam melakukan penelitian, kegiatan penelitian harus didasari ciri-ciri keilmuan yaitu rasional, empiris dan sistematis, apabila penulis melakukan penelitian dengan didasari ciri-ciri tersebut maka cara penelitian dapat dikatakan ilmiah. Kemudian penelitian yang dilakukan harus dengan cara-cara yang dapat dimengerti oleh penalaran manusia atau dalam kata lain cara penelitian yang dilakukan masuk akal itulah yang dimaksud dengan rasional, dan juga cara penelitian harus dapat diamati oleh indra manusia sehingga orang lain dapat mengetahui cara penelitian yang digunakannya itulah yang dimaksud empiris, kemudian yang terakhir sistematis maksudnya adalah langkah-langkah dalam penelitian dilakukan secara berurutan, tersistem, konsisten dan bersifat logis.

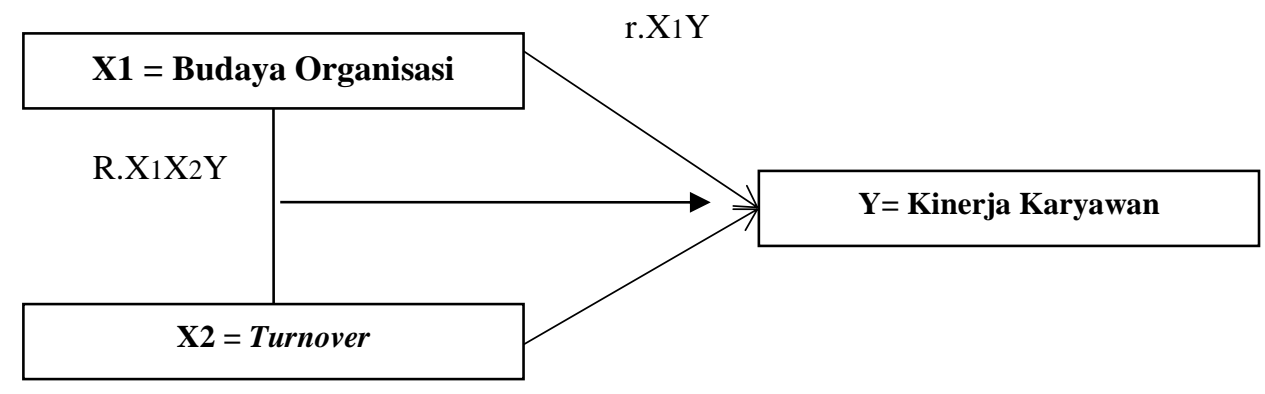

r.X2Y

\section{G. Hipotesis}

\section{Gambar 2.1. Diagram Model Penelitian}

Hipotesis adalah jawaban sementara untuk menjawab rumusan masalah penelitian dalam bentuk pernyataan, menurut Sugiyono (2013:134). Jawaban baru berdasarkan pada toeri oleh karena itu sifatnya dikaitkan sementara, dalam penelitian ini penulis membuat hipotesis untuk rumusan masalahnya, hipotesis yang dibuat penulis adalah :

H1 : Ho = Diduga Budaya Organisasi di PT Citra Rasa Betawi tidak berpengaruh positif dan signifikan secara parsial pada Kinerja karyawan.

H2 : Ho = Diduga Turnover di PT Citra Rasa Betawi tidak berpengaruh positif dan signifikan secara parsial pada Kinerja karyawan.

H3 : Ho = Diduga Budaya Organisasi dan Turnover di PT Citra Rasa Betawi tidak berpengaruh positif dan signifikan secara parsial dan simultan pada Kinerja karyawan.

\section{HASIL PENELITIAN}

Pegaruh antar variable penelitian dapat dilakukan dengan menganalisa hasil pengolahan data seperti diberikut :

\section{A. Hasil Analisis Deskriptif}

1. Variabel Budaya Organisasi (X1):

Bahwa presentasi budaya organisasi PT Citra Rasa Betawi dengan sampel yang berjumlah 250 karyawan mendapat tanggapan yang sangat baik, berdasarkan tanggapan karyawan dari 12 pernyataan yang memberi tanggapan "Sangat Setuju" sebesar 1209, (40.30\%), "Setuju” sebesar 1660 (55.33\%), "Ragu” sebesar 124 (4.13\%), "Tidak Setuju” sebesar 7 ( 0.23\%), "Sangat Tidak Setuju" sebesar $0(0.00 \%)$.

2. Variabel Turnover (X2) : 
Bahwa presentasi turnover PT Citra Rasa Betawi dengan sampel yang berjumlah 250 karyawan mendapat tanggapan sangat baik, berdasarkan tanggapan karyawan dari 12 pernyataan yang memberi tanggapan "Sangat Setuju" sebesar 915 (30.50\%), "Setuju" sebesar 1801 (60.03\%), "Ragu" sebaesar 276 (9.20\%), "Tidak Setuju" sebesar 7 ( 0.23\%), "Sangat Tidak Setuju" sebesar $1(0.03 \%)$. Yang memberi tanggapan "Tidak Setuju" dan "Sangat Tidak Setuju" dapat diambil sebagai saran untuk perbaikan di perusahaan dari hasil penelitian ini.

3. Variabel Kinerja (Y) :

Bahwa presentasi kinerja PT Citra Rasa Betawi dengan sampel yang berjumlah 250 karyawan mendapat tanggapan sangat baik, berdasarkan tanggapan karyawan dari 12 pernyataan yang memberikan tanggapan "Sangat Setuju" sebesar 795 (26.50\%), "Setuju" sebesar 1994 (66.47\%), "Ragu" sebesar 196 (6.53\%), "Tidak Setuju” sebesar 14 ( 0.47\%), "Sangat Tidak Setuju" sebesar $1(0.03 \%)$.

\section{B. Hasil Uji Kualitas Data}

Uji validitas dan uji realibilitas dapat dipergunakan untuk mengevaluasi kualitas suatu data yang diperoleh dari instrument-instrumen karya tulis ilmiah, maka akurasi data dari setiap instumen akan diketahui.

1. Hasil Uji Validitas

Acuan dalam sebuah penelitian ketika akan melakukan Uji Validitas dalam menetukan Validitas di setiap pernyataan yang tertera pada kuisioner kita dapat melakukan dengan mengetahui nilai rtabel produck moment, $d f=$ $(\alpha, n-2)$. Dengan jumlah 250 orang sebagai responden kemudian hasil perhitungan menunjukan nilai rtabel $=0,124$ dengan tingkat signifikan < 0,05 . Maka variabel dapat dinyatakan valid ketika $r$ hitung $>r$ table. Namun Variabel dinyatakan tidak valid ketika hasil $r$ negative serta $r$ hitung $<r$ table.

2. Hasil Uji Reliabilitas

Dalam sebuah penelitian suatu variabel dapat dilihat konsistensinye dengan melakukan Uji Reliabilitas. Menenurut Imam Ghozali (2007:133) dalam Uji Reliabilitas apabila Cronbach Alpha memiliki koefisien diatas 0,6 maka suatu pengukuran dinyatakan dapat diandalkan, seperti hasil perhitungan pada tabel dibawah ini :

Table 3.1

Hasil Uji Reliabilitas Data

\begin{tabular}{|c|l|c|c|}
\hline No & \multicolumn{1}{|c|}{ Variabel } & $\begin{array}{r}\text { Cronbach } \\
\text { Alpha }\end{array}$ & Kesimpulan \\
\hline 1 & Budaya Organisasi (X1) & 0,804 & Reliable \\
\hline 2 & Turnover (X2) & 0,850 & Reliable \\
\hline 3 & Kinerja (Y) & 0,868 & Reliable \\
\hline
\end{tabular}

\section{Pengujian Asumsi Klasik}

Untuk penulis dapat memastikan apakah model regresi linear berganda dalam penelitian ini dapat digunakan atau tidak, maka penulis harus melakukan 
pengujian asumsi klasik, pengujian asumsi klasik ini dilakukan pertama kemudian setelah itu kita dapat melakukan pengujian hipotesis.

\section{Hasil Uji Normalitas}

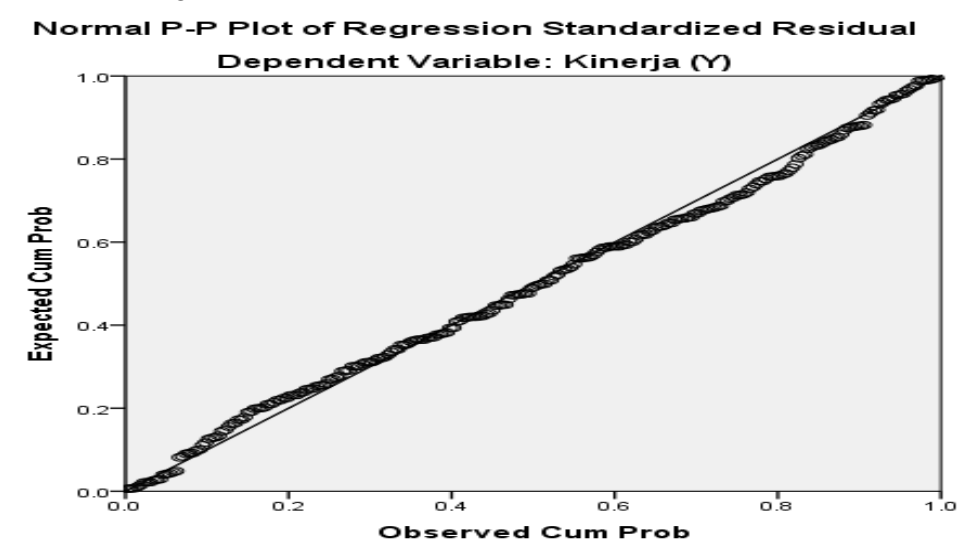

\section{Sumber : Hasil Olah Data SPSS}

Gambar 3.1 Uji Normalitas

Berdasarkan gambar 3.1 titi-titik terlihat mengikuti garis diagonal dan menyebar disekitar garis, artinya menunjukan nilai residual yang dihasilkan dari regresi tersbut normal.

\section{Uji Multikolinieritas}

Untuk membuktikan adanya kolerasi pada variable indevenden dalam model regresi biasanya dilakukan uji multikolinieritas. Menurut Ghozali (2007:134) variable independen akan membentuk model regresi yang baik ketika tidak terjadi kolerasi di antara variable indevenden dan dikatakan tidak orthogonal. VIF atau (Variance Inflation Factors)) biasanya digunakan mendeteksi adanya apakah ada gejala Multikolinieritas dalam penelitian ini. Gejala Multikolinierita dapat terjadi jika nilai VIF (Variance Inflation Factors) $>10$ dan nilai tolerance $<0,10$. Output dari SPSS terlihat tidak ada gejala multikolinieritas :

Table 3.2

$$
\text { Hasil Uji Multikolinieritas - VIF (Variance Inflation Factors) }
$$

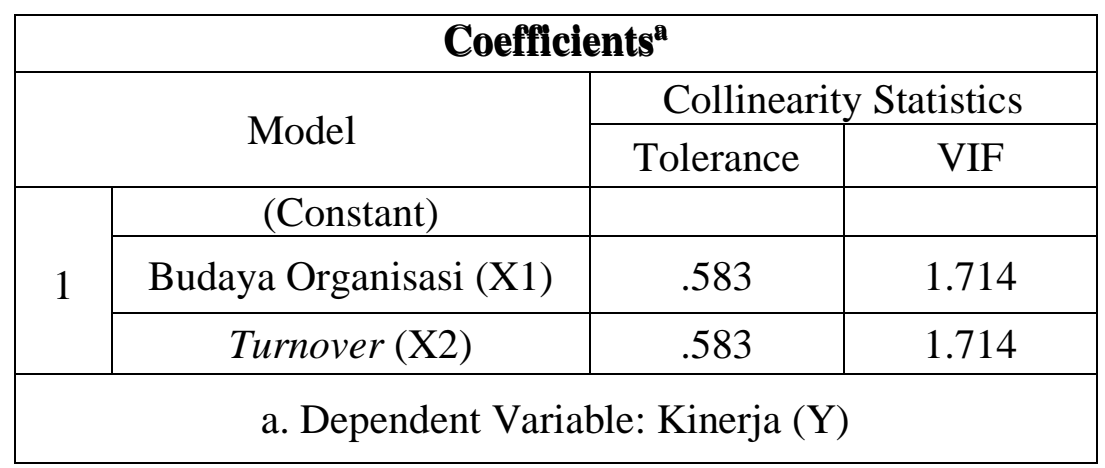

Untuk mengetahui apakah varian yang sama dimiliki oleh variable pengganggu atau tidak, kita dapat mengetahuinya dengan melakukan uji Heteroskedastisitas. Dalam model regresi tidak boleh ada gelaja Heterokedastsitas agar dapat memenuhi persyaratan. 


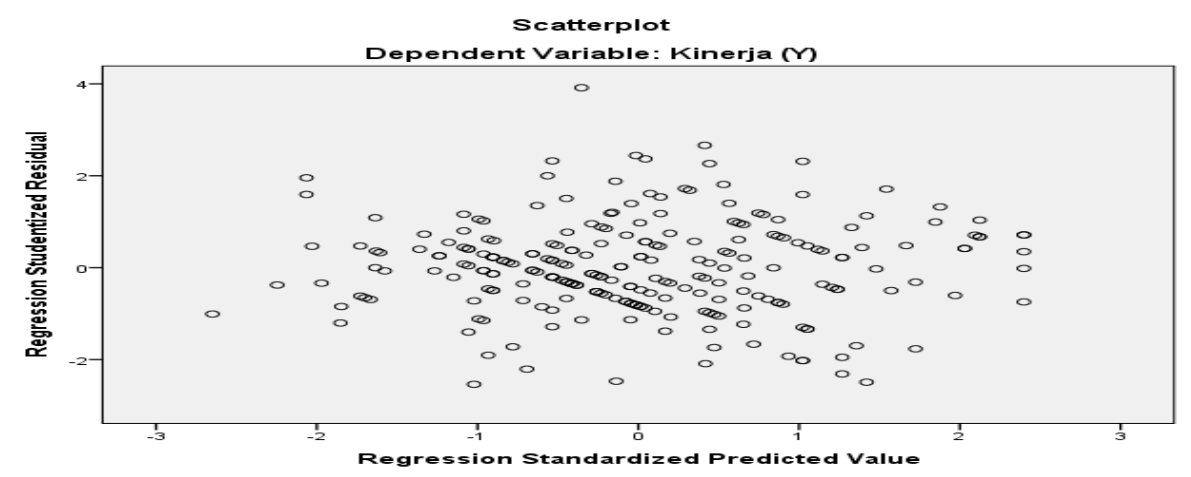

Gambar 3.2 Hasil Uji Heterokedastisitas

Output di gambar 3.2 atas terlihat dalam model regresi tidak terjadi masalah Heterokedastisitas hal ini terjadi karena tidak ada pola yang jelas dari sebaran titik-titik dan terlihat sebaran titi-titik berada diatas dan dibawah angka 0 sumbu Y.

\section{Uji Hipotesis}

\section{Hasil Pengujian Hipotesis Pertama (X1 ke Y)}

a. Uji t

Output pengujian secara parsial hipotesis pertama dari SPSS :

\section{Tabel 3.3}

Hasil Uji Parsial Hipotesis Pertama

\begin{tabular}{|c|c|c|c|c|c|c|}
\hline \multicolumn{7}{|c|}{ Coefficients $^{\mathbf{a}}$} \\
\hline & \multirow{2}{*}{ Model } & \multicolumn{2}{|c|}{$\begin{array}{l}\text { Unstandardized } \\
\text { Coefficients }\end{array}$} & \multirow{2}{*}{$\begin{array}{c}\text { Standardized } \\
\text { Coefficients }\end{array}$} & \multirow[t]{2}{*}{$\mathrm{T}$} & \multirow[t]{2}{*}{ Sig. } \\
\hline & & $\mathrm{B}$ & Std. Error & & & \\
\hline \multirow[b]{2}{*}{1} & (Constant) & 9.730 & 2.957 & & 3.290 & .001 \\
\hline & $\begin{array}{l}\text { Budaya } \\
\text { Organisasi (X1) }\end{array}$ & .776 & .056 & .658 & $\begin{array}{c}13.74 \\
9\end{array}$ & .000 \\
\hline
\end{tabular}

a. Dependent Variable: Kinerja (Y)

Sumber : Hasil pengolahan data menggunakan SPSS

b. Regresi Linier Sederhana

Budaya Organisasi di PT Citra Rasa Betawi berpengaruh terhadap kinerja karyawannya, hal ini dinyatakan oleh hasil uji hipotesis pertama, dalam tabel dibawah :

\section{Tabel 3.4}

Hasil Analisis Regresi Linier Hipotesis Pertama

\begin{tabular}{|c|c|c|c|c|c|c|}
\hline \multicolumn{7}{|c|}{ Coefficients $^{\mathrm{a}}$} \\
\hline & \multirow{2}{*}{ Model } & \multicolumn{2}{|c|}{$\begin{array}{l}\text { Unstandardized } \\
\text { Coefficients }\end{array}$} & \multirow{2}{*}{$\begin{array}{c}\text { Standardized } \\
\text { Coefficients } \\
\text { Beta } \\
\end{array}$} & \multirow[t]{2}{*}{$\mathrm{T}$} & \multirow[t]{2}{*}{ Sig. } \\
\hline & & B & Std. Error & & & \\
\hline \multirow[b]{2}{*}{1} & (Constant) & 9.730 & 2.957 & & 3.290 & .001 \\
\hline & $\begin{array}{l}\text { Budaya } \\
\text { Organisasi (X1) }\end{array}$ & .776 & .056 & .658 & 13.749 & .000 \\
\hline
\end{tabular}


Sumber : Hasil pengolahan data menggunakan SPSS

$\mathbf{Y}=\mathbf{9 . 7 3 0}+\mathbf{0 . 7 7 6 X 1}$ adalah persamaan regresi linear sesuai dengan tabel 3.4 di atas.

c. Koefisien Determinasi (R-Square)

Variable bebas budaya organisasi terhadap kinerja dapat diukur pengaruhnya dengan menggunakan nilai koefisien determinasi $\left(\mathrm{R}^{2}\right)$.

Tabel 3.5

Koefisien Determinasi Hipotesis Pertama

\begin{tabular}{|c|c|c|c|c|c|}
\hline \multicolumn{7}{|c|}{ Model Summary $^{\text {bodel }}$} & $\mathrm{R}$ & R Square & $\begin{array}{l}\text { Adjusted } \\
\text { R Square }\end{array}$ & $\begin{array}{c}\text { Std. Error of } \\
\text { the Estimate }\end{array}$ & $\begin{array}{c}\text { Durbin- } \\
\text { Watson }\end{array}$ \\
\hline 1 & $.658^{\mathrm{a}}$ & .433 & .430 & 3.212 & 1.889 \\
\hline \multicolumn{7}{|l|}{ a. Predictors: (Constant), Budaya Organisasi (X1) } \\
\hline
\end{tabular}

Sumber : Hasil pengolahan data menggunakan SPSS

2. Hasil Pengujian Hipotesis Kedua (X2 ke Y)

a. Uji t

Output secara parsial dari SPSS :

Tabel 3.6

Hasil Uji Parsial Hipotesis Kedua

\begin{tabular}{|c|c|c|c|c|c|c|}
\hline \multicolumn{7}{|c|}{ Coefficients $^{\mathrm{a}}$} \\
\hline & \multirow{2}{*}{ Model } & \multicolumn{2}{|c|}{$\begin{array}{l}\text { Unstandardized } \\
\text { Coefficients }\end{array}$} & \multirow{2}{*}{$\begin{array}{c}\begin{array}{c}\text { Standardized } \\
\text { Coefficients }\end{array} \\
\text { Beta }\end{array}$} & \multirow{2}{*}{$\mathrm{T}$} & \multirow{2}{*}{ Sig. } \\
\hline & & B & $\begin{array}{l}\text { Std. } \\
\text { Error }\end{array}$ & & & \\
\hline \multirow[b]{2}{*}{1} & (Constant) & 14.575 & 2.228 & & 6.542 & .000 \\
\hline & $\begin{array}{l}\text { Turnover } \\
\text { (X2) }\end{array}$ & .708 & .044 & .715 & $\begin{array}{c}16.08 \\
8\end{array}$ & .000 \\
\hline
\end{tabular}

Sumber : Hasil pengolahan data menggunakan SPSS

b. Regresi Linier Sederhana

Hasil uji hipotesis kedua Turnover seperti pada tabel dibawah terlihat memiliki pengaruh kepada Kinerja Karyawan pada PT Citra Rasa Betawi artinya Kinerja karyawan di PT Citra Rasa Betawi dapat dipengaruhi oleh turnover.

Tabel 3.7

Hasil Analisis Regresi Linier Hipotesis Kedua

\begin{tabular}{|c|c|c|c|c|c|c|}
\hline \multicolumn{7}{|c|}{ Coefficients $^{\mathrm{a}}$} \\
\hline & \multirow{2}{*}{ Model } & \multicolumn{2}{|c|}{$\begin{array}{l}\text { Unstandardized } \\
\text { Coefficients }\end{array}$} & \multirow{2}{*}{$\begin{array}{c}\begin{array}{c}\text { Standardized } \\
\text { Coefficients }\end{array} \\
\text { Beta }\end{array}$} & \multirow{2}{*}{$\mathrm{T}$} & \multirow{2}{*}{ Sig. } \\
\hline & & B & $\begin{array}{l}\text { Std. } \\
\text { Error }\end{array}$ & & & \\
\hline 1 & (Constant) & 14.575 & 2.228 & & 6.542 & .000 \\
\hline
\end{tabular}




\begin{tabular}{|l|l|l|l|l|c|c|}
\hline $\begin{array}{l}\text { Turnover } \\
\text { (X2) }\end{array}$ & .708 & .044 & .715 & $\begin{array}{c}16.08 \\
8\end{array}$ & .000 \\
\hline
\end{tabular}

a. Dependent Variable: Kinerja (Y)

Sumber : Hasil pengolahan data menggunakan SPSS

$\mathbf{Y}=\mathbf{1 4 . 5 7 5}+\mathbf{0 . 7 0 8 X 2}$ adalah persamaan regresi linear dalam penelitian ini sesuai dengan tabel 3.7

c. Koefisien Determinasi (R-Square)

Variable bebas Turnover terhadap kinerja dapat diukur pengaruhnya dengan menggunakan nilai koefisien determinasi $\left(\mathrm{R}^{2}\right)$.

Tabel 3.8

Koefisien Determinasi Hipotesis Kedua

\begin{tabular}{|c|c|c|c|c|c|}
\hline \multicolumn{7}{|c|}{ Model Summary $^{\mathbf{b}}$} \\
\hline Model & $\mathrm{R}$ & R Square & $\begin{array}{c}\text { Adjusted R } \\
\text { Square }\end{array}$ & $\begin{array}{c}\text { Std. Error of } \\
\text { the Estimate }\end{array}$ & $\begin{array}{c}\text { Durbin- } \\
\text { Watson }\end{array}$ \\
\hline 1 & $.715^{\mathrm{a}}$ & .511 & .509 & 2.983 & 1.874 \\
\hline a. Predictors: (Constant), Turnover (X2) \\
\hline
\end{tabular}

Sumber : Hasil pengolahan data menggunakan SPSS

R Square sebesar 0.511. artinya Variabel Kinerja (Y) dapat dipengaruhi oleh Variabel Turnover (X2) sebesar 51.1\% sedangkan $48.9 \%$ pengaruh variable lainnya yang belum di teliti.

\section{Hasil Pengujian Hipotesis Ktiga (X1, X2 ke Y)}

a. Hasil Regresi Berganda Hipotesis Ketiga

Budaya Organisasi dan Turnover berpengaruh pada Kinerja Karyawan pada PT Citra Rasa Betawi secara serempak dan untuk dapat melihat apakah Variabel Budaya Organisasi (X1) dan Variabel Turnover (X2) memberikan pengaruh yang posistif pada Variabel Kinerja Karyawan (Y) pada PT Citra Rasa Betawi dinyatakan oleh uji regresi berganda hipotesis ketiga.

Tabel 3.9

Koefisien Regresi Berganda Hipotesis Ketiga

\begin{tabular}{|c|c|c|c|c|c|c|}
\hline \multicolumn{7}{|c|}{ Coefficients $^{\mathrm{a}}$} \\
\hline & \multirow{2}{*}{ Model } & \multicolumn{2}{|c|}{$\begin{array}{c}\text { Unstandardized } \\
\text { Coefficients }\end{array}$} & \multirow{2}{*}{$\begin{array}{c}\begin{array}{c}\text { Standardized } \\
\text { Coefficients }\end{array} \\
\text { Beta }\end{array}$} & \multirow{2}{*}{$\mathrm{T}$} & \multirow{2}{*}{ Sig. } \\
\hline & & B & $\begin{array}{l}\text { Std. } \\
\text { Error }\end{array}$ & & & \\
\hline \multirow{3}{*}{1} & (Constant) & 4.669 & 2.618 & & 1.784 & .076 \\
\hline & $\begin{array}{c}\text { Budaya Organisasi } \\
\text { (X1) }\end{array}$ & .397 & .064 & .337 & 6.214 & .000 \\
\hline & Turnover (X2) & .492 & .054 & .497 & 9.178 & .000 \\
\hline
\end{tabular}

Sumber : Hasil pengolahan data menggunakan SPSS

$\hat{\mathbf{Y}}=\mathbf{4 . 6 6 9}+\mathbf{0 . 3 9 7 X} 1+\mathbf{0 . 4 9 2 X} 2$ adalah persamaan regresi berganda sesuai tabel 3.9 di atas. 


\section{b. Koefisien Determinasi (R-Square)}

Variable bebas Budaya Organisasi dan Turnover terhadap kinerja dapat diukur pengaruhnya dengan menggunakan nilai koefisien determinasi $\left(\mathrm{R}^{2}\right)$.

Tabel 3.10

Koefisien Determinasi Hipotesis Ketiga

\begin{tabular}{|c|c|c|c|c|c|}
\hline \multicolumn{6}{|c|}{ Model Summary ${ }^{b}$} \\
\hline Model & $\mathrm{R}$ & R Square & $\begin{array}{l}\text { Adjusted } \\
\text { R Square }\end{array}$ & $\begin{array}{l}\text { Std. Error of } \\
\text { the Estimate }\end{array}$ & $\begin{array}{l}\text { Durbin- } \\
\text { Watson }\end{array}$ \\
\hline 1 & $.760^{\mathrm{a}}$ & .577 & .573 & 2.780 & 1.958 \\
\hline \multicolumn{6}{|c|}{ a. Predictors: (Constant), Turnover (X2), Budaya Organisasi (X1) } \\
\hline \multicolumn{6}{|c|}{ b. Dependent Variable: Kinerja (Y) } \\
\hline
\end{tabular}

Sumber : Hasil pengolahan data menggunakan SPSS

R Square sebesar 0.573. artinya Variabel Kinerja (Y) dapat dipengaruhi oleh Variabel Budaya Organisasi (X1) dab Turnover (X2) sebesar $57.3 \%$ sedangkan $42.7 \%$ pengaruh variable lainnya yang belum di teliti.

\section{c. Uji Serempak Hipotesis Ketiga (Uji F)}

Tabel 3.11

\section{Hasil Uji Serempak Hipotesis Ketiga}

\begin{tabular}{|c|c|c|c|c|c|c|}
\hline \multicolumn{7}{|c|}{ ANOVA $^{\text {a }}$} \\
\hline \multirow{2}{*}{ Model } & $\begin{array}{c}\text { Sum of } \\
\text { Squares }\end{array}$ & Df & $\begin{array}{c}\text { Mean } \\
\text { Square }\end{array}$ & F & Sig. \\
\hline \multirow{2}{*}{1} & $\begin{array}{c}\text { Regressio } \\
\mathrm{n}\end{array}$ & 2601.371 & 2 & 1300.685 & $\begin{array}{c}168.3 \\
53\end{array}$ & $.000^{\mathrm{b}}$ \\
\cline { 2 - 7 } & Residual & 1908.313 & 247 & 7.726 & & \\
\cline { 2 - 7 } & Total & 4509.684 & 249 & & & \\
\hline \multicolumn{7}{|c|}{ a. Dependent Variable: Kinerja (Y) } \\
\hline \multicolumn{7}{|c|}{ b. Predictors: (Constant), Turnover (X2), Budaya Organisasi (X1) } \\
\hline
\end{tabular}

Sumber : Hasil pengolahan data menggunakan SPSS

Nilai Fhitung 168.353 > Ftabel 3.07, dan Sig. 0,000 < alpha 5\% (0.05). artinya secara berssma-sama variable bebas (indevenden) berpengarush signifikan dan positif pada variable terikan (devenden).

\section{E. Pembahasan}

1. Pengaruh (X1) terhadap (Y) secara parsial.

Pengaruh posistif dan signifikan terjadi secara parsial antara (X1) terhadap (Y). hal ini ditunjukan dengan nilai thitung $13.749>$ ttabel 1.974. atau Sig $0.000<0.05$, Ho ditolak kemudian Ha diterima, antara (X1) terhadap (Y). Tingkat hubungan (X1) terhadap (Y) sebesar 0.658 artinya (X1) memiliki tingkat hubungan yang kuat terhadap (Y).

2. Pengaruh (X2) terhadap (Y) secara parsial.

Pengaruh posistif dan signifikan terjadi secara parsial antara (X2) terhadap (Y). hal ini ditunjukan dengan nilai thitung 16.088 > ttabel 1.974. atau Sig $0.000<0.05$, Ho ditolak kemudian Ha diterima, antara (X1) 
terhadap (Y). Tingkat hubungan (X1) terhadap (Y) sebesar 0.715 artinya (X1) memiliki tingkat hubungan yang kuat terhadap (Y).

3. Pengaruh (X1) dan (X2) terhadap (Y) secara simultan.

Pengaruh posistif dan signifikan terjadi secara simultan antara (X1) dan (X2) terhadap (Y). hal ini ditunjukan dengan nilai Fhitung $168.353>$ Ftabel 3. atau Sig $0.000<0.05$, Ho ditolak kemudian Ha diterima,

Dari hasil regresi linear berganda yang telah ditemukan adalah $\hat{Y}=$ $4.669+0.397 \mathrm{X} 1+0.492 \mathrm{X} 2$ dimana konstanta sebesar 4.669 menyatakan bahwa tanpa (X1) dan (X2), besarnya nilai (Y) tetap terbentuk 4.669. kemudian (X1) berpengaruh positif terhadap terhadap (Y) dengan nilai koefisien sebesar 0.397. yang artinya jika (X1) meningkat satu satuan, maka (Y) akan meningkat sebesar 0.39 , dan (X2) berpengaruh positif terhadap terhadap (Y) dengan nilai koefisien sebesar 0.429. yang artinya jika (X2) meningkat satu satuan, maka (Y) akan meningkat sebesar 0.429. Nilai Adjustes R Square sebesar 0.573 yang menunjukan bahwa (Y) dipengaruhi oleh (X1) dan (X2) sebesar 57,3\% dan sisanya sebesar 42,7\% dipengaruhi oleh variable lain yang belum diteliti.

\section{KESIMPULAN}

Penulis lakukan penelitian di PT Citra Rasa Betawi, perusahaan yang bergerak dibidang restoran, saat ini kantor pusatnya berlokasi di J1. Ponco II No.28, Gandaria selata, Cilandak Jakarta Selatan, penelitian dilakukan selama tiga bulan pada tahun 2018. Berdasarkan hasil pembahasannya maka penulis memberikan kesimpulan dari hasil penelitian :

1. Di PT Citra Rasa Betawi Budaya Organisasi (X1) berpengaruh posistif dan signifikan kepada Kinerja Karyawan (Y) secara parsial.

2. Di PT Citra Rasa Betawi Turnover (X2) berpengaruh posistif dan signifikan kepada Kinerja Karyawan (Y) secara parsial.

3. Di PT Citra Rasa Betawi Budaya Organisasi (X1) dan Turnover (X2) berpengaruh posistif dan signifikan kepada Kinerja Karyawan (Y) secara simultan.

4. Di PT Citra Rasa Betawi Kinerja Karyawan (Y) akan lebih baik jika Budaya Organisasi (X1) dan Turnover (X2) diperbaiki.

5. PT Citra Rasa Betawi harus memperhatikan variable lain yang belum diteliti dalam penelitian ini, karena sebenarnya masih banyak variable lain yang dapat mempengaruhi Kinerja karyawan agar tujuan atau mimpi dari perusahaan dapat tercapai.

\section{SARAN}

Penulis memberikan saran untuk PT Citra Rasa Betawi sebagai berikut :

1. Penulis memberikan saran agar perusahaan dapat meningkatkan integritas karyawan dan memastikan agar karyawannya dapat bekerja dengan lebih professional.

2. Penulis memberikan saran agar perusahaan dapat meningkatkan peluang berkarier untuk para karyawannya, agar karyawan memiliki masa depan dengan jenjang kariernya dan tingkat turnover karyawan menurun.

3. Penulis memberikan saran agar perusahaan dapat meningkatkan inisiatif karyawan dalam bekerja agar terjadi peningkatan kinerja karyawan.

4. Penulis memberikan saran agar PT Citra Rasa Betawi dapat menjaga dan memperbaiki segala nilai dan norma-norma yang sudah baik dan sudah diberlakukan di perusahaannya, PT Citra Rasa Betawi harus mau mendengar apa yang menjadi 
aspirasi, usulan atau gagasan dari para karyawannya dan berusaha memenuhi harapan para karyawannya.

5. Penulis memberikan saran agar PT Citra Rasa Betawi bisa menjadi tempat kerja terbaik dimana tersedia jenjang karier dan semua karyawannya diakui sebagai bagian dari keluarga besar, karyawan diakui sebagai asset yang memiliki nilai tinggi sehingga PT Citra Rasa Betawi dapat memperlakukan karyawan dengan sangat baik, menjaga dan meningkatkan nilai yang ada pada karyawan.

6. Menurut penulis rumus sukses mengelola sebuah perusahaan adalah perusahaan harus memiliki tujuan yang jelas, kemudian sejahterakan kebutuhan karyawan, kemudian ajak karyawan mencapai tujuan perusahaan agar perusahaan sehat, untung dan dapat terus memberikan kesejahteraan pada karyawannya. Jika rumus ini dibalik, perusahaan berharap karyawan membuat perusahaannya untung, membuat perusahaannya sehat baru karyawan akan disejahterakan maka selama perusahaan sibuk berharap seperti itu para karyawan akan sibuk untuk mencapai kesejahteraan sendiri bahkan mungkin bisa saja karyawan akan sibuk mencari peluang di perusahaan lain.

\section{DAFTAR PUSTAKA}

Ghozali,Imam. (2007). Aplikasi Analisis Multi Variat dengan Program SPSS. Semarang: Penerbit Universitas Diponegoro.

Hani, Handoko T. (2008). Manajemen Personalia dan Sumber Daya Manusia. Yogyakarta : BPFE.

Hartono. (2002). Manajemen Sumber Daya Manusia (Edisi 2). Jakarta: PT.Prehallindo.

Mangkunegara, Anwar Prabu. (2005). Perilaku dan Budaya Organisasi. Bandung : PT.Rafika.

Aditama-. (2011). Manajemen Sumber daya Manusia Perusahaan. Bandung: Remaja Rosdakarya.

Mathis, R.L. Jackson, J.H. (2006). Manajemen Sumber Daya Manusia, Jakarta: Salmba Empat.

Viethzal Ravai, (2009). "Manajemen Sumber Daya Manusia untuk Perusahaan".

Jakarta: -. (2009). Kepemimpinan dan Perilaku Organisasi. Jakarta: Raja Grafindo Persada. 